\title{
PENGARUH PEMBELAJARAN TEAM GAMES TOURNAMENTS TERHADAP EMPATI SISWA
}

\author{
Ruli Sugiawardana ${ }^{1}$ dan Hendra Rustiawan ${ }^{2}$ \\ Universitas Galuh Ciamis, Indonesia \\ email: hendra6610111972@gmail.com
}

\begin{abstract}
ABSTRAK. Tujuan penelitian ini adalah untuk mengetahui pembelajaran team games tournament (TGT) terhadap empati siswa. Metode penelitian menggunakan eksperimen one- group pretest-postest design hanya menggunakan satu kelompok penelitian. Populasi penelitian di SMA N 3 Kabupaten Ciamis. Menggunakan Kelompok usia antara 17-20 tahun tersebut dipilih yang layak untuk dijadikan sampel penelitian berjumlah 30 orang. Teknik penelitian ini menggunakan teknik total sampling. Instrumen yang akan digunakan dalam penelitian ini adalah skala empati. Hasilnya adalah pembelajaran team games tournament memberikan pengaruh yang signifikan terhadap peningkatan empati pada siswa SMA N 3 Kabupaten Ciamis.
\end{abstract}

Kata Kunci: Empati; Pembelajaran; Team games tournament

\section{Pendahuluan}

Peningkatan kualitas sumber daya manusia merupakan syarat mutlak untuk mencapai tujuan pembangunan. Salah satu cara untuk meningkatkan kualitas sumber daya manusia tersebut adalah pendidikan (Indri, 2017) Peningkatan hasil belajar yang dicapai oleh siswa dipengaruhi oleh beberapa faktor, baik yang berasal dari diri siswa (faktor internal) maupun dari luar siswa (faktor external) (Hapnita, Abdullah, dan Gusmareta, 2017). Faktor internal diantaranya adalah minat, bakat, motivasi dan tingkat intelegensi. Sedangkan faktor external diantaranya adalah metode pembelajaran dan kondisi lingkungan sekolah. Guru sebagai instrumen mempengaruhi perkembangan dan kemajuan peserta didik (Susilonuringsih, 2006). Hal ini berkaitan erat dengan orientasi mengajar kepada siswa. Namun apabila profesi guru berorientasi pada penghasilan yang lebih besar, akan berdampak pada siswa yang secara perlahan akan menurunkan kualitas siswanya (Fitriana, 2008). Namun guru yang berorientasi kepada kendala dan permasalahan yang dihadapi siswa akan menghasilkan peserta didik yang reflektif, yakni peserta didik yang sadar mengenai kekurangan dan mengoptimalkan aspek kelebihannya (Dasmaniar, 2018). Guru yang berorientasi pada pengembangan siswa biasanya memiliki kemampuan dalam menerapkan teknik pembeajaran dengan menggunakan pendekatan cooperative learning sangat beragam (Esthi Santi Ningtyas, 2017).

Terdapat beberapa tipe pembelajaran kooperatif, yaitu: Jigsaw II, Student Teams Achievement Devition (STAD), Team Assisted Individualization (TAI), Teams Game Tournament (TGT), Group Investigation (GI) dan metode structural (Haryati, 2017). Dalam penelitian ini hanya akan menggunakan model pembelajaran kooperatif dengan tipe Teams 
Game Tournament TGT. Dalam upaya melaksanakan tuntutan gerak psikomotor yang lebih komplek maka perlu ada upaya-upaya kreatif memilih model pembelajaran yang harus dilakukan oleh guru. Pembelajaran dengan menggunakan model pembelajaran kooperatif (Widhiastuti;Fachrurrozie, 2014). Aktivitas belajar dengan permainan yang dirancang dalam pembelajaran kooperatif memungkinkan siswa dapat belajar lebih rileks disamping menumbuhkan tanggung jawab, kejujuran, kerja sama, persaingan sehat dan keterlibatan belajar (Sekarwati, 2015).

Pada pembelajaran yang berpusat pada siswa seperti pada model pembelajaran kooperatif, harapan seorang guru adalah siswa dapat lebih aktif dalam melakukan pembelajaran khususnya pada siswa SMA N 3 Kabupaten Ciamis, namun pada kenyataan di lapangan harapan ini sering tidak sepenuhnya terpenuhi. Penyebab tidak terpenuhinya harapan ini salah satunya bisa terjadi apabila guru kurang kreatif dalam metode pembelajaran pada saat pembelajaran berlangsung (Sekarwati, 2015). Dan ditambah lagi habitt/kebiasaan dari siswa yang memang kurang begitu berminat untuk mengikuti pembelajaran (Dewantara, 2016), dan hal ini juga terjadi pada hampir semua mata pelajaran dan yang lebih menghawatirkan siswa yang datang kesekolah seakan-akan hanya sekedar rutinitas dan pada akhirnya lulus mendapatkan ijazah. Dari landasan permasalahan inilah yang mendorong penulis yang sekaligus sebagai Guru di SMA N 3 ingin memberikan sebuah model pembelajaran kooperatif dengan harapan yaitu adanya perubahan dari siswa yang pada awalnya hanya melakukan aktifitas karena tuntutan dari sekolah menjadi sebuah kebutuhan yang menyenangkan bagi siswa itu sendiri dan terlebih jika hasil dari pembelajaran penjas yang signifikan, sesuai dengan tujuan pendidikan jasmani. Salah satu kompetensi gerak yang dicantumkan pada kompetensi dasar pendidikan jasmani adalah melakukan gerakan keterampilan motorik dasar (Sudjana, 2016).

Gerakan motorik dasar meliputi lari dan jalan. Dan itu terdapat dalam pendidikan jasmani. Peneliti sangat ingin mengkaji masalah yang terjadi untuk mengetahui pengaruh pembelajaran kooperatif TGT yang dapat meningkatkan hasil belajar pada pembelajaran pendidikan jasmani dan khususnya untuk meningkatkan kemauan siswa secara sadar untuk berperan aktif dalam pembelajaran penjas, karena pada zaman ini yang serba modern dan canggih dapat menumbuhkan ego manusia tumbuh secara sendiri-sendiri dan kerjasama merupakan suatu barang yang mahal (Syawal, 2018). Untuk itu penulis ingin menumbuhkan perasaan dalam diri siswa ketika mengikuti pembelajaran penjas dan tidak hanya itu, ikut serta dalam suatu tidakan yang nyata, hal tersebut dapat dinamakan empati (Sukma, Puspita, 
\& Gumelar, 2017). Atas dasar penjelasan di atas, penulis merasa tertarik untuk melakukan penelitian tentang empati dengan menggunakan model pembelajaran team games tournament.

\section{Metode Penelitian}

Penulis menggunakan metode eksperimen yaitu Pre-Experimental One-Group Pretest-Postest Design. Penelitian ini untuk mengetahui sejauh mana hasil yang diperoleh apakah hasil dari penelitian ini adanya peningkatan secara signifikan atau tidak, dengan kata lain peningkatan tidak terpaku pada besar atau kecil hasilnya.

Penelitian eksperimen adalah suatu kegiatan percobaan untuk melihat suatu hasil sebagaimana yang dicobakannya. Penggunaan metode eksperimen dalam penelitian ini berarti penulis harus mengadakan percobaan terhadap kelompok subjek yang akan menerima perlakuan tertentu dalam masa waktu tertentu, kemudian setelah masa percobaan ini selesai selanjutnya dilihat hasil dari perlakuan tersebut. Variabel penelitian ini terdiri dari variabel bebas dan variabel terikat. Variabel bebasnya adalah model pembelajaran teams games tournament (TGT), sedangkan variabel terikatnya adalah empati. Populasinya adalah siswa SMA N 3 Kabupaten Ciamis. Kelompok usia antara 17-20 tahun tersebut dipilih yang layak untuk dijadikan sampel penelitian berjumlah 30 orang. Teknik penelitian ini menggunakan teknik Total Sampling. Instrumen yang akan digunakan dalam penelitian ini adalah skala empati (Ginting, 2009) menjelaskan skala empati menggunakan skala likert. Masing-masing terdiri dari empat alternatif jawaban yaitu : sangat sesuai (SS), sesuai (S), kurang setuju (KS), tidak sesuai (TS), sangat tidak sesuai (STS).

\section{Hasil dan Pembahasan}

\section{Deskripsi Data}

Deskripsi data menyajikan hasil pengolahan data secara deskriptif yang disajikan dalam bentuk tabel dan grafik diagram.

Tabel 1

Deskripsi Data Tes Awal Empati

\begin{tabular}{|c|c|c|c|c|c|c|}
\hline Kelompok Sampel & $\mathrm{N}$ & $\begin{array}{c}\text { Rata- } \\
\text { Rata }\end{array}$ & $\begin{array}{c}\text { Standar } \\
\text { Deviasi }\end{array}$ & Varians & $\begin{array}{c}\text { Skor } \\
\text { Terendah }\end{array}$ & $\begin{array}{c}\text { Skor } \\
\text { Tertinggi }\end{array}$ \\
\hline $\begin{array}{c}\text { Tes Awal Kel. Teams } \\
\text { Games Tournaments }\end{array}$ & 30 & 83.10 & 2.09 & 4.36 & 78 & 86 \\
\hline
\end{tabular}

Dari tabel 1 dapat diketahui nilai rata-rata tes awal kelompok teams games tournaments adalah 83.10, dengan standar deviasi 2.09 dan varians 4.36. Sedangkan skor terendah adalah 78 sedangkan skor tertingginya adalah 86 . 
Tabel 2

Deskripsi Data Tes Akhir Empati

\begin{tabular}{|c|c|l|l|l|c|c|}
\hline Kelompok Sampel & N & $\begin{array}{l}\text { Rata- } \\
\text { Rata }\end{array}$ & $\begin{array}{c}\text { Standar } \\
\text { Deviasi }\end{array}$ & Varians & $\begin{array}{c}\text { Skor } \\
\text { Terendah }\end{array}$ & $\begin{array}{c}\text { Skor } \\
\text { Tertinggi }\end{array}$ \\
\hline $\begin{array}{c}\text { Tes Akhir Kel. Teams } \\
\text { Games Tournaments }\end{array}$ & 30 & 84.33 & 2.10 & 4.43 & 79 & 87 \\
\hline
\end{tabular}

Dari tabel 2 dapat diketahui nilai rata-rata tes awal kelompok teams games tournaments adalah 84.33, dengan standar deviasi 2.10 dan varians 4.43. Sedangkan skor terendah adalah 79 sedangkan skor tertingginya adalah 87.

Hasil Uji Normalitas

Tabel 3.

Uji Normalitas Tes awal dan Tes Akhir Empati

\begin{tabular}{|lc|c|c|c|}
\hline \multirow{2}{*}{ Kelompok } & \multicolumn{3}{|c|}{ Kolmogorof-Smirnov } \\
\cline { 3 - 5 } & & Statistik & df & Sig \\
\hline Tes Awal. & Tes empati & 0.248 & 30 & 0.125 \\
Tes Akhir & Tes empati & 0.237 & 30 & 0.123 \\
\hline
\end{tabular}

Kriteria Keputusan :

1. Nilai Sig. atau probabilitas $<0.05$ ( Distribusi tidak normal)

2. Nilai Sig. atau probabilitas > 0.05 ( Distribusi Normal) Uji Kenormalan :

1. Tes awal: Kelompok Tendangan Empati: Sig. $0.125>0.05$ (Distribusi Normal)

2. Tes Akhir: Kelompok Permainan Loncat Karet: Sig. $0.123>0.05$ (Distribusi Normal)

Berdasarkan kriteria keputusan dan uji kenormalan dari tabel 4.3 diketahui bahwa data tes empati hasil tes awal dan tes akhir kelompok teams games tournaments berdistribusi normal. Dengan demikian salah satu syarat untuk pengolahan statistik parametrik sudah tercapai. Untuk lebih jelas penulis mencantumkan grafik tes awal dan tes akhir.

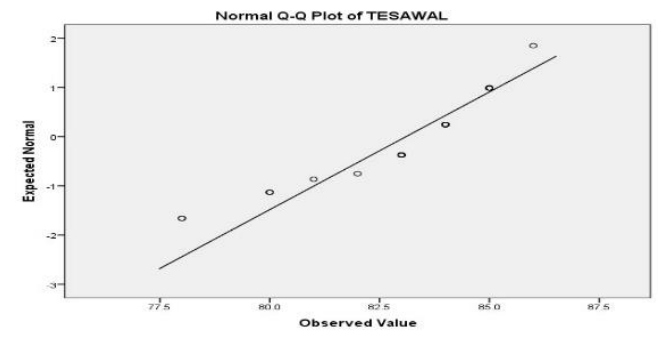

Grafik 1

Hasil Uji Normalitas Tes Awal Kelompok Teams games Tournaments 


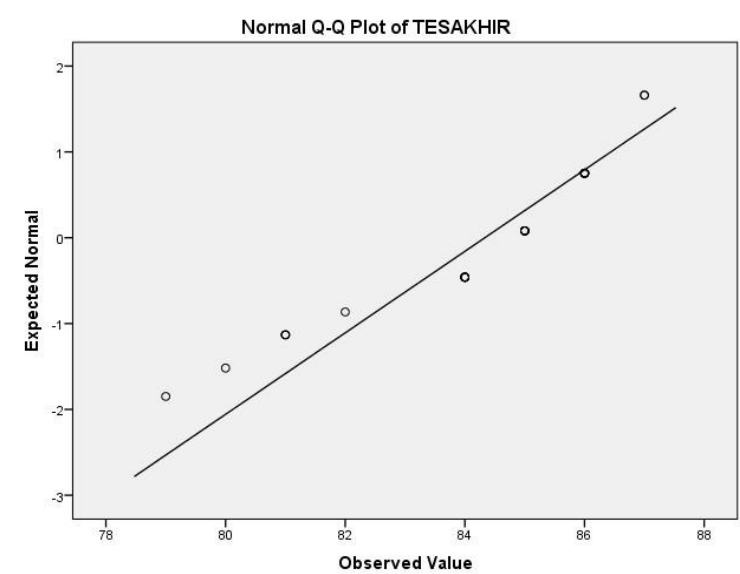

Hasil Uji Normalitas Tes Akhir Kelompok Teams games Tournaments

Penjelasan grafik di atas adalah sebagai berikut:

Dari ke-dua grafik di atas terlihat garis diagonal atau garis miring dari kiri ke kanan atas. Jika suatu distribusi data normal, maka data akan tersebar di sekeliling garis (Prawira, 2012:53). Sehingga dapat disimpulkan bahwa kedua kelompok tersebut berdistribusi normal. Berdasarkan hasil analisa data tersebut, dapat disimpulkan bahwa penelitian dari kelompok team games tournament baik pada tes awal maupun tes akhir berdistribusi normal karena titik-titik data tersebar di sekitar garis dan mengikuti arah diagonal garis.

\section{Uji Hipotesis}

Langkah pertama yang akan dilakukan pada hipotesis ini uji-t menggunakan Paired sample ttest untuk mengolah data hasil rata-rata tes awal dan tes akhir dari ke dua kelompok penelitian. Hal ini sesuai dengan pemdapat Priyatno (2012:84) menjelaskan, "Uji-t untuk sampel berpasangan atau paired sample t-test digunakan untuk menguji perbedaan rata-rata antara dua sample yang berpasangan yaitu sebelum dan sesudah mendapatkan perlakuan atau pelatihan”. Pengujian dilakukan dua sisi, dimana nilai probabilitas (Sig.) maupun dk masingmasing dibagi 2. Untuk lebih jelas penulis mencantumkan data hasil uji hipotesis menggunakan paired sample t-test, dalam bentuk tabel hanya mencantumkan data pentingnya saja dari keseluruhan data secara lengkap agara mudah dimengerti, sedangkan data uji hipotesis secara lengkap dapat dilihat pada bagian lampiran. Untuk itu tabel hasil uji paired sample t-test dapat dilihat sebagai berikut. 
Tabel 4

Paired Sample t-test Kelompok

\begin{tabular}{|l|l|c|c|c|c|c|c|}
\hline \multicolumn{2}{|l|}{} & $\begin{array}{l}\text { Rata } \\
\text {-rata }\end{array}$ & $\begin{array}{c}\text { Std. } \\
\text { Deviasi }\end{array}$ & $\mathrm{T}$ & $\mathrm{dk}$ & $\begin{array}{c}\text { Sig. } \\
\text { (2-tailed) }\end{array}$ & Ket \\
\hline $\begin{array}{l}\text { Kelompok Team } \\
\text { games } \\
\text { Tournaments }\end{array}$ & $\begin{array}{l}\text { Tes awal dan } \\
\text { tes akhir } \\
\text { empati }\end{array}$ & 1.23 & 0.43 & 15.70 & 29 & 0.000 & Signifikan \\
\hline
\end{tabular}

Merumuskan Hipotesis :

1. Ho = Tidak ada perbedaan teams games tournaments antara tes awal dan tes akhir secara signifikan terhadap empati pada siswa SMA N I Sukadana Kabupaten Ciamis.

2. $\mathrm{Ha}=$ Ada perbedaan teams games tournaments antara tes awal dan tes akhir secara signifikan terhadap empati pada siswa SMA N I Sukadana Kabupaten Ciamis.

3. Menentukan $t$ hitung

Dari output diketahui nilai t hitung adalah 15.70

4. Mentukan $t$ tabel

T tabel dapat dilihat pada tabel statistic pada signifikansi $0.05: 2=0.025$ (uji 2 sisi) dengan derajat kebebasan (df) n-1 atau 30-1 =29, hasil diperoleh untuk t tabel sebesar 2.093 / - 2.093. (Lihat pada lampiran tabel). Kriteria Pengujian:

Jika $-\mathrm{t}$ tabel $\leq \mathrm{t}$ hitung $\leq \mathrm{t}$ tabel maka Ho diterima

Jika $-\mathrm{t}$ hitung $<-\mathrm{t}$ tabel atau $\mathrm{t}$ hitung $>\mathrm{t}$ tabel maka Ho ditolak

Berdasar Signifikansi : Jika Signifikansi > 0.05 maka Ho diterima dan jika Signifikansi $<0.05$ maka Ho ditolak.

Membuat kesimpulan nilai - $\mathrm{t}$ hitung < - t tabel. (- 15.70 < - 2.093) maka Ho ditolak. Jadi dapat disimpulkan bahwa ada peningkatan hasil teams games tournaments terhadap empati pada siswa SMA N I Sukadana Kabupaten Ciamis.

\section{Pengambilan keputusan berdasarkan Signifikansi.}

Berdasar signifikansi, jika signifikansi $<0.05$ maka Ho ditolak, dan jika signifikansi > 0.05 maka Ho diterima. Karena signifikansi $(0.000<0.05)$ maka Ho ditolak. Artinya ada peningkatan skala empati hasil teams games tournaments setelah diberikan model pembelajaran kooperatif menggunakan teams games tournaments. Berdasarkan hasil pengolahan dan analisis data, secara empirik model pembelajaran kooperatif dalam bentuk teams games tournaments (TGT) memberikan pengaruh yang signifikan terhadap skala 
empati pada siswa SMA N I Sukadana Kabupaten Ciamis. Secara lengkap pembahasan hasil latihan akan dijelaskan sebagai berikut:

Hipotesis penulis menunjukan terbukti dengan mencantumkan data hasil uji normalitas, mulai dari uji tes normalitas tes awal yaitu $0.125>0.05$ yang artinya bahwa sampel penelitian termasuk pada data normal. Demikian pula dengan tes akhir yaitu 0.123>0.05 yang artinya bahwa sampel penelitian termasuk pada data normal. Akhirnya penulis menympulkan bahwa data tes empati hasil tes awal dan tes akhir kelompok teams games tournaments berdistribusi normal.

Pelaksanaan teams games tournaments di dalam mata pelajaran penjas pada siswa SMA N 3 Kabupaten Ciamis tidak hanya mengembangkan fisik, tetapi juga mengembangkan nilai atau sikap karakter dan sikap sosial termasuk didalamnya mengembangkan emosi mental yang sehat dan yang paling utama adalah pengembangan rasa empati yang cukup baik terbukti dari hasil pengamatan pada siswa bisa lebih mengembangkan sikap sosialnya dan empati terhadap teman satu

tim.

Tingkatan empati siswa yang tinggi atau cukup baik terlihat pada masing- masing individu di dalam setiap kelompok terlihat bahwa para siswa tersebut ternyata mengikuti kegiatan olahraga baik ekstrakurikuler olahraga atau bergabung dengan klab kecabangan olahraga di luar sekolah. Sehingga para siswa yang dijadikan sampel penelitian sudah terbiasa dengan sistem solidaritas dan kerjasama tim yang baik.

Pendidikan jasmani dengan menerapkan model pembelajaran kooperatif yaitu teams games tournaments memiliki peran yang cukup penting dalam mengembangkan empati siswa. Dampak dari pendidikan jasmani dan olahraga salah satunya adalah adanya perbaikan hubungan sosial misalnya munculnya empati. Dimana empati merupakan rasa hormat dalam hubungan dan dalam mengendalikan sikap.

\section{Kesimpulan}

Berdasarkan hasil analisis data yang sudah dijelaskan sebelumnya, penulis menyimpulkan bahwa model pembelajaran kooperatif menggunakan teams games tournaments berpengaruh secara berarti terhadap peningkatan empati pada siswa SMA N 3 Kabupaten Ciamis. Untuk itu sesuai dengan hipotesis penulis menyimpulkan bahwa, pembelajaran team games tournament memberikan pengaruh yang signifikan terhadap peningkatan empati pada siswa SMA N 3 Kabupaten Ciamis. 


\section{Daftar Pustaka}

Dasmaniar. (2018). Survey Tentang Masalah-Masalah yang Dihadapai oleh Siswa Kelas VIII SMP Negeri 1 INUMAN. PAJAR (Pendidikan Dan Pengajaran), 1, 65-75.

Dewantara, I. P. M. (2016). Alternatif Strategi Pembelajaran Keterampilan Berbicara. Jurnal Santiaji Pendidikan, 6(1), 38-49.

Esthi S. N, E. W. (2017). Penerapan Model Pembelajaran Kooperatif (Cooperative Learning) Tipe Make-A Match Berbantuan Media Komik Interaktif Untuk Meningkatkan Aktivitas Belajar Dan Hasil Belajar IPS. Jurnal Pendidikan Surya Edukasi (JPSE), 3(1), 66-74.

Fitriana, A. S. dan S. (2008). Pentingnya Profesionalisme Guru dalam Meningkatkan Kualitas Pendidikan. UPGRIS.

Ginting, A. O. (2009). Hubungan Empati dengan Cooperative Learning pada Proses Belajar Siswa di SMP Negeri 10 Medan. Universitas Sumatra Utara.

Haryati, S. (2017). Belajar dan Pembelajaran Berbasis Pembelajaran Kooperatif. Magelang: Graha Cendikia.

Indri, S. (2017). Ilmu Kesejahteraan Keluarga Peningkatan Kualitas SDM melalui Pendidikan. Jakarta.

Sekarwati, S. (2015). Penerapan Model Teams Games Tournament untuk Meningkatkan Aktivitas dan Hasil Belajar Fisika di SMP.

Sudjana, I. P. A. A. T. I. N. (2016). Metode Keterampilan Gerak Dasar Lokomotor Menggunkan Metode Bermain dalam Pembelajaran Pendidikan Jasmani Siswa Kelas III C SDN Krian 3 Kabupaten Sidoarjo. PENDIDIKAN JASMANI, 26(02), 229-237.

Sukma, R., Puspita, D., \& Gumelar, G. (2017). Pengaruh Empati terhadap Perilaku Prososial dalam Berbagi Sosial di Jejaring Sosial Twitter. Jurnal Penelitian dan Pengukuran Psikologi. https://doi.org/10.21009/JPPP.031.01

Susilonuringsih, K. (2006). Pengaruh Faktor Intern dan Faktor Ekstern terhadap Minat Belajar Siswa Kelas I di SMK Yayasan Pendidikan Ekonomi (YAPEK) GOMBONG TAHUN DIKLAT 2005 / 2006 SKRIPSI. Universitas Negeri Semarang.

Syawal, H. (2018). Psikoanalisis Sigmund Freud dan Implikasinya dalam Pendidikan, (March).

Widhiastuti \& Fachrurrozie, R. (2014). Teams Games Tournament (TGT) sebagai Metode untuk Meningkatkan Keaktifan dan Kemampuan Belajar. JURNAL PENDIDIKAN EKONOMI DINAMIKA PENDIDIKAN, IX (1), 48-56.

Widia, H., Rijal, A. \& Yuwalitas Gusmareta, F. R. (2017). Faktor Internal dan Eksternal yang Dominan Siswa Kelas Xi Teknik Gambar Bangunan SMK N 1 Padang Tahun 2016 / 2017. CIVED, 5(1), 2175-2182. 